\title{
Does Quantity Generate Quality? Testing the Fundamental Principle of Brainstorming
}

\author{
Alfredo Muñoz Adánez \\ Universidad Complutense de Madrid
}

The purpose of this work is to test the chief principle of brainstorming, formulated as "quantity generates quality." The study is included within a broad program whose goal is to detect the strong and weak points of creative techniques. In a sample of 69 groups, containing between 3 and 8 members, the concurrence of two commonly accepted criteria was established as a quality rule: originality and utility or value. The results fully support the quantity-quality relation $(r=.893)$ : the more ideas produced to solve a problem, the better quality of the ideas. The importance of this finding, which supports Osborn's theory, is discussed, and the use of brainstorming is recommended to solve the many open problems faced by our society.

Keywords: brainstorming, withholding judgement, creativity, problem solving

Dentro de un amplio programa cuyo objetivo es detectar los puntos fuertes y débiles de
las técnicas creativas, en el presente trabajo ponemos a prueba el principio fundamental
del brainstorming formulado en los siguientes términos: "la cantidad genera calidad".
Trabajamos con una muestra de 69 grupos, de entre 3 y 8 miembros cada uno, y
establecemos como norma de calidad la conjunción de los dos criterios comúnmente
aceptados: originalidad y utilidad o valor. Los resultados obtenidos apoyan plenamente
la relación entre cantidad y calidad ( $r=.893$ ): cuanto mayor sea el número de ideas
producidas en relación con un problema, mayor será el número de ideas de calidad. Se
comenta la importancia de este hallazgo en apoyo de la teoría de Osborn y se recomienda
el uso del brainstorming en la resolución de la multitud de problemas abiertos que nuestra
sociedad tiene planteados.
Palabras clave: brainstorming, aplazamiento del juicio, creatividad, resolución de problemas

Correspondence concerning this article should be addressed to Alfredo Muñoz Adanez, Sección Departamental de Psicología Social, Universidad Complutense de Madrid, Facultad de Psicología, Campus de Somosaguas, 28223 Madrid (Spain). E-mail: chaviris@psi.ucm.es

Translation: Virginia Navascués Howard 
Maslow (1971) began his chapter on creativity with this significant sentence: "My feeling is that the concept of creativeness and the concept of a healthy, self-actualizing, fully human person seem to be coming closer and the closer together, and may perhaps turn out to be the same thing." Amabile $(1983,1998)$ revealed the close relationship between creativity and intrinsic motivation, doubtless the crucial motivational pattern if individuals can be expected to become totally involved in their actions (Gómez Campelo \& Muñoz Marrón, 2003; Muñoz Adánez, 2003; Muñoz Adánez, Muñoz Marrón, \& Ruiz Pérez, 2000; Ochoa \& Muñoz Adánez, 2003). The close relationship that seems to exist between selfrealization on the one hand and intrinsic motivation on the other reveals the relevance of creativity in the evolution of mankind and its influence on key aspects of personal development. Therefore, creativity is given a privileged position in this investigation. The focus of studies on creativity may be partially flawed, so the topic has become quite attractive but is meaningless when attempting to influence the course of our lives. It is a common fact that anything that sounds like creativity is taken frivolously, identifying creativity with the absence of rules, irresponsibility, and lack of importance and rigor. Although objective reality is far removed from this perception, something must have occurred to make this idea so widespread in most people's minds.

The works on creativity are full of very suggestive anecdotes and more or less illustrative examples of what creativity is and how it works, but there are not many solid ideas that direct the elaboration of plans for the creative enhancement of people, groups, and society, and when such ideas do emerge, there are no controlled experiences that support the strength of the arguments, connect creativity to problem-solving, in the sense of Wertheimer (1959), or show unequivocally that creativity can help us to cope efficiently with the many problems we face.

There are interesting contributions of authors such as Amabile (1983, 1998), Csikszentmihalyi (1996), Sternberg and Lubart (1995), and Paulus and Nijstad (2003), and creative methods, such as those of Crawford (1954), Osborn (1957), Gordon (1961), Zwicky (1969), Moles and Caude (1970), Prince (1970), and DeBono (1970), have been proposed for problem-solving. But neither the works mentioned nor the methods created seem to have produced the research that leads to the creation of a solid, stable, and unquestionable body of knowledge on which to base creativity.

The most practical ideas may come from creative methods, but here also we find very interesting ideas that have not awakened the relevant interest in the subsequent research. We are often left with attractive intuitions that seemed to work, but that not even their authors could be bothered to support them with detailed and rigorous investigations, confirming the efficiency of their rich suggestions. We need to know whether such methods work and why and in what conditions. We need precision, rigor, and practical suggestions to guide people and groups, so they would know what to expect at each step of the problem- solving process. That is, we need tools to make problems more manageable and, eventually, to find possible solutions.

Brainstorming is doubtless the method that has provoked the most research (Osborn, 1957), but even nowadays we still do not know what to expect with regard to the chief principle on which it is based. In fact, we find as many data in favor of brainstorming (Brillhart \& Jochem, 1964; Parnes, 1963; Parnes \& Meadow, 1959; Paulus \& Brown, 2003; Rowatt, Nesselroade, Beggan, \& Allison, 1997) as against it (Langelar, 1970; Mullen, Johnson, \& Salas, 1991; Weisberg, 1986; Wisskopf-Joelson \& Eliseo, 1961).

The focuses of this work is therefore to examine the truth of the chief principle of brainstorming, which, in the words of Osborn (1957), could be expressed as "quantity generates quality" or, according to the advice of Csikszentmihalyi (1996), "produce as many ideas as you can," the principle around which the whole functioning of this method revolves. According to this principle, the more ideas produced to solve a problem, the better they will be. This is why all brainstorming efforts are aimed at producing the largest possible number of ideas, proposing two basic conditions to achieve the effect: withholding judgment and teamwork (Muñoz Adánez, 1994). Brainstorming is chosen for two important reasons: First, it is the most well known and cited method; and second, because I believe that up till now, due to its improper use, not all the possibilities it provides have been exploited (Muñoz Adánez).

When stating that quality depends on quantity, it is assumed that, theoretically, any idea is valid, which is why one should practice withholding judgment or suspending criticism during the idea production stage (Osborn, 1957). No doubt, the acceptance of the notion that quality depends on quantity defies common sense and the predominant educational system, in which, on principle, only correct ideas are admitted - with the consequent disapproval of wrong or incorrect responses-, and in which error is punished-with unavoidable consequences in terms of inhibition, protection of self-esteem, and fear of making mistakes.

When judging the quality of ideas, there is an unavoidable problem: the establishment of some criteria to make decisions. When does an idea have quality? What prerequisites should an idea have to be considered a quality idea? The clearest, unanimously accepted, criterion is that of originality or exceptionality, generally defined as statistical infrequency.

However, originality may also appear in wild, incoherent, or aberrant products. A large number of pathological behaviors are statistically infrequent, but they can hardly be called creative. What are they lacking to be considered creative? What characteristic, along with originality, imparts quality on a product? There is a general consensus that this criterion is utility or value. The sense of this characteristic becomes clear if its broad meaning is taken into account: It refers to those solutions that can be considered useful, practical, valid, adequate, coherent, sensible, or adapted to the problem. That is, this refers to any idea that contributes something to the solution of the problem and that does not go against logic or common sense. 
As a function of the goals pursued, I propose the following hypothesis: In problem solving, the groups that produce more ideas will be more creative, that is, they will offer more quality ideas.

Method

\section{Participants}

Participants in this study were 325 men and women (266 women and 59 men), from 21 to 27 years old, mean age 22 years $(S D=1.58)$. There were 69 groups, each one comprised between 3 and 8 members.

\section{Procedure}

The experiences were carried out during various courses on creativity and problem solving, for which the participants had been receiving training in brainstorming.

Participants were requested to solve a classic creativity problem and that generally is called the normal uses problem. In this case, participants were asked to suggest the "possible uses of a tin can." Emphasis was placed on withholding judgment and suspending criticism during the idea-production phase. Participants were allowed 20 minutes in which to generate ideas.

\section{Data Analysis}

The following data were obtained from each group: total number of ideas produced, number of original ideas, number of useful ideas, and number of quality ideas (originality + utility).

The criterion of originality was previously fixed at an appearance frequency of not higher than $1 \%$ of the total number of different ideas obtained. As there were 516 different responses, any idea that appeared between 1 and 5 times was considered original. A committee made up of eight experts in creative thinking determined the utility criterion. The experts decided whether the ideas were useful, practical, whether they solved the problem, were adapted to it, or contributed something to the problem. Any idea that achieved this appraisal by at least six of the eight experts (75\%) was considered useful.

Pearson's correlation $(r)$ was calculated to find a possible relationship between quantity and quality.

\section{Results}

The results obtained are displayed in Table 1 and in Chart 1 , in which the data are arranged according to the quantity of ideas produced. Chart 1 is shows the general increase of quality ideas as the quantity of ideas per group increases, although there were several noteworthy exceptions. Pearson's correlation between the variables quantity and quality was $r=.893, p<.01$.
Table 1

Quantity of Ideas and Number of Quality Ideas in each Group

\begin{tabular}{|c|c|c|}
\hline Group $\mathrm{Nr}$ & $\begin{array}{c}\text { Quantity of } \\
\text { ideas }\end{array}$ & $\begin{array}{l}\text { Number of } \\
\text { Quality ideas }\end{array}$ \\
\hline 1 & 12 & 3 \\
\hline 2 & 15 & 2 \\
\hline 3 & 15 & 3 \\
\hline 4 & 18 & 1 \\
\hline 5 & 18 & 4 \\
\hline 6 & 19 & 0 \\
\hline 7 & 19 & 1 \\
\hline 8 & 19 & 2 \\
\hline 9 & 21 & 1 \\
\hline 10 & 21 & 1 \\
\hline 11 & 21 & 2 \\
\hline 12 & 22 & 3 \\
\hline 13 & 23 & 0 \\
\hline 14 & 23 & 1 \\
\hline 15 & 24 & 1 \\
\hline 16 & 25 & 3 \\
\hline 17 & 26 & 1 \\
\hline 18 & 26 & 5 \\
\hline 19 & 26 & 5 \\
\hline 20 & 27 & 7 \\
\hline 21 & 27 & 10 \\
\hline 22 & 28 & 0 \\
\hline 23 & 28 & 2 \\
\hline 24 & 28 & 2 \\
\hline 25 & 28 & 10 \\
\hline 26 & 29 & 4 \\
\hline 27 & 29 & 7 \\
\hline 18 & 29 & 7 \\
\hline 29 & 29 & 8 \\
\hline 30 & 30 & 3 \\
\hline 31 & 30 & 7 \\
\hline 32 & 30 & 3 \\
\hline 33 & 31 & 1 \\
\hline 34 & 32 & 3 \\
\hline 35 & 32 & 6 \\
\hline 36 & 33 & 8 \\
\hline 37 & 33 & 8 \\
\hline 38 & 34 & 1 \\
\hline 39 & 34 & 3 \\
\hline 40 & 34 & 5 \\
\hline 41 & 34 & 6 \\
\hline 42 & 34 & 8 \\
\hline 43 & 35 & 4 \\
\hline 44 & 37 & 4 \\
\hline 45 & 37 & 9 \\
\hline 46 & 39 & 7 \\
\hline 47 & 39 & 13 \\
\hline 48 & 40 & 4 \\
\hline 49 & 42 & 13 \\
\hline 50 & 43 & 5 \\
\hline 51 & 44 & 6 \\
\hline 52 & 47 & 7 \\
\hline 53 & 47 & 11 \\
\hline 54 & 48 & 7 \\
\hline 55 & 50 & 3 \\
\hline 56 & 50 & 12 \\
\hline 57 & 51 & 8 \\
\hline 58 & 53 & 9 \\
\hline 59 & 54 & 11 \\
\hline 60 & 57 & 12 \\
\hline 61 & 58 & 16 \\
\hline 62 & 62 & 18 \\
\hline 63 & 63 & 13 \\
\hline 64 & 66 & 26 \\
\hline 65 & 72 & 17 \\
\hline 66 & 76 & 13 \\
\hline 67 & 81 & 13 \\
\hline 68 & 93 & 22 \\
\hline 69 & 152 & 49 \\
\hline
\end{tabular}




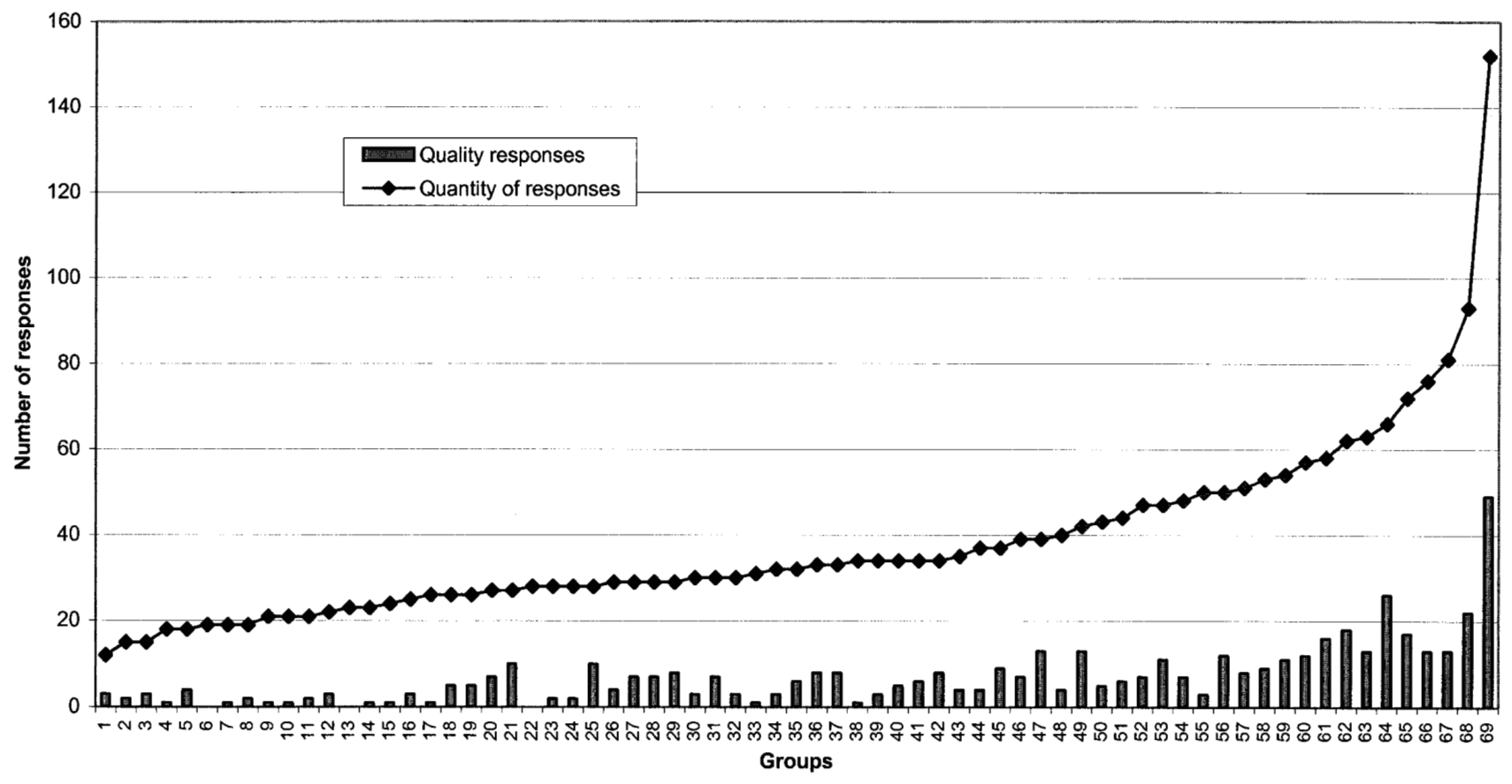

Figure 1. Quantity and quality of ideas during brainstorming.

\section{Discussion}

The first and main conclusion derived from the data obtained is that, in effect, quantity generates quality: As the production of ideas increases, there is more likelihood of more quality ideas appearing. The groups that contributed more solutions to the problem offered more quality solutions. Thus, the hypothesis is confirmed, in accordance with the theory of Osborn (1957). It is therefore advisable to promote the production of ideas to solve problems.

There are several explanations to this phenomenon. The first is that the more common ideas are used up in the first approximations to the problem, and thus, the ideas that emerge later on, once the more common ones are depleted, are more original. Thus, the groups that produced fewer ideas for the problem contributed more common ideas than did the groups that persisted and continued to produce more ideas. The second explanation is that the atmosphere of trust, freedom, and cooperation that was created enhanced the emergence of the participants' creativity as ideas are produced. A third possible explanation is that participants learn to be more creative with practice. Lastly, one could also speculate that the production of ideas itself encourages participants to go on producing, with the subsequent reward in terms of quality. In any case, the fact that quality increases with the passing of time corroborates the idea that it is necessary to allow enough time so that creative problemsolving productivity can shine in its entire splendor.

Although it is clear that the principle is fulfilled, there are some noteworthy exceptions. The more relevant exceptions are of two types: (a) the groups that, although not remarkable for the quantity of ideas produced, obtain a high number of quality ideas (for example, groups 21 and 25); and (b) the groups that produce many ideas, but with a scarce amount of quality ideas (for example, groups 38 and 55).

Guilford (1962) suggests that perhaps Hyman (1960) was right when stating that quantity can lead to an improvement in the quality of certain types of problems, but not in all types. Similarly, some of the contradictory results found in the bibliography may be explained by taking into account the different variables that may affect the efficiency of the method (type and complexity of problem, time allowed, work atmosphere, members' personality, number of group components, motivation, leader's capacity, etc. ). No matter what, it is clear that more studies are required like the present one but using different types of problems, differentiating both the theme and the complexity or other kinds of variables, in order to verify whether the same results are achieved.

One of the limitations of this study is that the time allowed for the production of ideas was limited to 20 minutes, a time lapse in which it is not possible to use the techniques than favor the production of ideas (chaining ideas, crazy ideas, control lists, etc.). It is logical to assume that the use of these techniques and having more time would favor even more significant results.

As exceptions to the rule were observed in some groups, an explanation should be found in order to foresee this and extract some lesson to improve the method. In the case of the groups of quality without quantity, it is possible that very original, but not very motivated, people may have been randomly grouped into these units; or that the participants 
did not withhold judgment, thus creating a climate of inhibition in which only original ideas were formulated. The leader may also have favored quality instead of quantity. In the groups of quantity without quality, several causes could also be proposed. Probably, fluidity was promoted instead of flexibility, leading to the production of many ideas from the same category; it is also possible that not very creative, but highly motivated, people were randomly grouped into these units.

In both kinds of exceptions, one assumes that the groups could have produced more quality ideas. In the first case, by attempting to get them to produce more ideas, perhaps by clearly instructing them to withhold judgment or by using auxiliary techniques. In the second case, by the leader's action, inducing the group members to change their perspective when looking at the problem.

Aside from these exceptions, some notable facts were found. The most significant is that a high percentage of the groups produced a small number of ideas, with the subsequent scarcity of quality ideas. This may be due to the lack of motivation of the group members, to the leader's inappropriate behavior, or to the fact that the necessary climate of freedom was not produced in the group, with inhibition predominating over spontaneity.

Another interesting fact is that some of the groups were capable of producing 81,93 , and up to 152 ideas, while in the same time, other groups did not reach 20 ideas. There must be many variables involved in these results, but one aspect is quite evident: with more frequency than it is reasonable to expect, teams do not reach the goal of their labor, either because they do not put in enough effort or because they do not achieve the climate that really leads to teamwork.

However, in general, the results lead one to trust the brainstorming principle and to establish the two conditions proposed by the method (withholding judgment and teamwork). Consequently, this principle and these conditions should be applied to cope with the multiple problems that face our society. But putting this method into practice means taking into account a series of circumstances without which the hoped-for results are not likely to be achieved.

The first condition is that withholding judgment must be practiced by the team, if one expects all the components to behave freely, with trust and spontaneity, and the team to work appropriately. There are data that show that the results are the fruit of withholding judgment (Muñoz Adánez, 1993) because thereby, certain social conditions_one could say mental conditions - are created that allow individuals to explore all the possibilities of their minds, to play with ideas, to trust in the group as a producer of ideas, to incubate ideas for some time, to become enthusiastic about the ideas and with the reality of creating, and to enjoy creating.

Second, there must be a group structure in which the figures of the leader, the secretary, and the participants are clearly differentiated, with the group leader carrying out his or her function efficiently.
The third condition is that the leader should be an expert in creating thinking, creative techniques, directing work teams, and establishing a climate of freedom.

Fourth, each and every one of the group members must be motivated to solve the problem.

Lastly, the need to have sufficient time to cope with the problem should be mentioned. Groups, and especially creative groups, must work without time pressure.

There are some unanswered questions that may be the subject of future studies. For example, one wonders whether the method produces more creative persons or whether their creativity is circumscribed to the time when they are working on a specific problem. Similarly, it should be verified whether the method works in more relevant problems, as well as the possible consequences derived from withholding judgment. A topic of enormous relevance is the identification of the cognitive, emotional, and social variables that generate the appropriate climate for creative teamwork, as it seems that many conditions are required for its productivity (Osborn, 1957; Rawlinson, 1981). Lastly, given its importance in group functioning, I wish to underscore the need to study in depth the factors of motivational and cognitive stimulation, which have been mentioned in previous investigations (Brown, Tumeo, Larey, \& Paulus, 1998; Paulus, Dugosh, Dzindolet, Coskun, \& Pulman, 2002).

Nowadays, when all kinds of problems arise in our lives, in these times of globalization, when many problems are acquiring planetary dimensions, we need more than ever to have access to our creative potential. It is extremely important to make the effort so that some of the problems that affect us as individuals_-such as social networks — and as a species begin to be considered as having a possible solution. Reality presents us with the evidence of our distrust of creativity or our fear of the nefarious consequences that could derive from leaving well-traveled roads when coping with problems. The education we have received may be at the bottom of this fact; however, researchers should not be absolved from their responsibility, as they have not known how to provide the depth and rigor that should predominate references to creativity.

\section{References}

Amabile, T.M. (1983). The social psychology of creativity. New York: Springer Verlag.

Amabile, T.M. (1998). How to kill creativity. Harvard Business Review, 76, 76-88.

Brillhart, J.K., \& Jochem, L.M. (1964). Effects of different patterns on outcomes of problem-solving discussions. Journal of Applied Psychology, 48, 175-179.

Brown, V., Tumeo. M., Larey, T.S., \& Paulus, P.B. (1998). Modeling cognitive interactions during group brainstorming. Small Group Research, 29, 495-526,

Crawford, P.R. (1954). Techniques of creative thinking. New York: Hawthorn Books. 
Csikszentmihalyi, M. (1996). Creativity. Flow and the psychology of discovery and invention. New York: Harper Collins.

DeBono, E. (1970). Lateral thinking. New York: Harper \& Row

Gómez Campelo, P., \& Muñoz Marrón, E. (2003). El desarrollo de la creatividad en una empresa humanizada. Encuentros en Psicología Social, 1, 74-76.

Gordon, W.J.J. (1961). Synectics. The development of creative capacity. New York: Harper \& Row.

Guilford, J.P. (1962). Factors that aid and hinder creativity. Teachers College Record, 63, 380-392.

Hyman, H. (1960). Some experiments in creativity. New York: General Electric Company

Langelar, J.W. (1970). Is brainstorming really effective? Mens en Onderneming, 24, 194-201.

Maslow, A. (1971). The farther reaches of human nature. Hamondsworth, UK: Penguin Books.

Moles, A., \& Caude, R. (1970). Créativité et méthodes d'innovation. Paris: Fayard-Mame.

Mullen, B., Johnson, C., \& Salas, E. (1991). Productivity loss in brainstorming groups: A meta-analytic integration. Basic and Applied Social Psychology, 12, 3-23.

Muñoz Adánez, A. (1993). El aplazamiento del juicio como elemento fundamental para el funcionamiento del grupo en el brainstorming. In F. Loscertales \& M. Marín (Eds.), Dimensiones psicosociales de la educación y de la comunicación, pp. 505-510. Sevilla, Spain: Eudema.

Muñoz Adánez, A. (1994). Métodos creativos para las organizaciones. Madrid: Eudema.

Muñoz Adánez, A. (2003). La naturaleza de la empresa humanizada. Encuentros en Psicología Social, 1, 77-78.

Muñoz Adánez, A., Muñoz Marrón, E., \& Ruiz Pérez, A. (2000, September). Características de la empresa humanizada. $1^{\text {st }}$ Hispanic-Portuguese Congress of Psychology.

Ochoa, A., \& Muñoz Adánez, A. (2003). La motivación intrínseca como variable clave para la humanización de las organizaciones. Encuentros en Psicología Social, 1, 70-73.

Osborn, A. (1957). Applied imagination. New York: Charles Scribner's Sons.

Parnes, S.J. (1963). Education and creativity. Teachers College Record, 64, 331-339.
Parnes, S.J., \& Meadow, A. (1959). Effect of "brainstorming" instructions on creative problem-solving by trained und untrained subjects. Journal of Educational Psychology, 50, 171-176.

Paulus, P.B., \& Brown, V.R. (2003). Enhancing ideational creativity in groups. Lessons from research on brainstorming. In P.B. Paulus \& B.A. Nijstad (Eds.), Group creativity. Innovation through collaboration, pp. 110-136. New York: Oxford University Press.

Paulus, P.B., Dugosh, K.L., Dzindolet, M.T., Coskun, H., \& Pulman, V.L. (2002). Social and cognitive influences in group brainstorming: Predicting production gains and losses. In W. Stroebe \& H. Hewstone (Eds.), European review of social psychology, 12, 300-325. London: Wiley.

Paulus. P.B., \& Nijstad, B.A. (Eds.). (2003). Group creativity. Innovation through collaboration. New York: Oxford University Press.

Prince, G.M. (1970). The practice of creativity. New York: Harper \& Row.

Rawlinson, J.G. (1981). Creative thinking and brainstorming. New York: Wiley.

Rowatt, W.C., Nesselroade, K.P., Beggan, J.K., \& Allison, S.T. (1997). Perceptions of brainstorming in groups: The quality over quantity hypothesis. Journal of Creative Behavior, 31, 131-150.

Sternberg, R.J., \& Lubart, T.I. (1995). Defying the crowd, cultivating creativity in a culture of conformity. New York: Free Press.

Weisberg, R.W. (1986). Creativity. Genius and other myths. New York: Freeman.

Wertheimer, M. (1959). Productive thinking. New York: Harper \& Row

Wisskopf-Joelson, E., \& Eliseo, T.S. (1961). An experimental study of the effectiveness of brainstorming. Journal of Applied Psychology, 45, 45-49.

Zwicky, F. (1969). Discovery, invention, research through the morphological approach. New York: Macmillan.

Received December 23, 2004

Revision received June 24, 2005

Accepted July 12, 2005 